\title{
The Impact of Firm Size, Leverage, Firm Age, Media Visibility and Profitability on Sustainability Report Disclosure
}

\author{
Maryana $^{1^{*}}$, Yenni Carolina ${ }^{2}$ \\ 1,2 Accounting, Economy, Maranatha Christian University, Indonesia. \\ *Corresponding Author: maryanasonjaya01@gmail.com
}

\begin{abstract}
This study aims to see the impact of firm size, leverage, firm age, media visibility, and industry affiliation on sustainability reporting disclosure as measured by the score of the GRI indicator. This study uses multiple linear regressions with E-views software. This study also utilizes pollution from firms that are admitted to the LQ 45 index listed on the BEI from 2014 to 2018. The research sample used was 18 purposive sampling method selected firms. The results of this study that have been processed simultaneously are that firm size, leverage, firm age, media visibility and profitability have a significant impact on SR disclosure. Partially, Firm Size and Media Visibility do not have a significant impact on SR disclosure. Leverage and Firm Age have a negative and significant impact on SR disclosure, while profitability has a positive and significant impact on SR disclosure.
\end{abstract}

Keywords

: Financial Performance; Firm Size; Firm Age; Leverage; Media

JEL Classification Visibility; Sustainability Reporting : G38

\section{INTRODUCTION}

In line with the development of an era, where social issues and environmental issues are the public concern, firms are required not to focus only on profits. The balance of the firm's focus on getting maximum profit and attention to the environment and the surrounding community has now become a public demand. There are many social and environmental issues in Indonesia, from the mudflow incident in Sidoarjo that occurred due to the operations of PT. Lapindo to issues of human rights and preservation of tribes at PT. Freeport, that has increasingly opened people's eyes to the firm's transparency and accountability in relation to the firm's daily activities, which are summarized on its sustainability report (SR). A sustainability report (SR) is a report published by a firm or organization that includes the economic, environmental, and social impacts caused by the firm's daily activities. SR is designed to help firms to plan, prepare, report and disclose information about their commitment, implementation, measurement, disclosure, and accountability for their management performance in economic, social, and environmental issues. Also, corporate governance to internal and external stakeholders in realizing sustainable corporate goals (Ariyani \& Hartomo, 2018). Nasir (2018) as a Menristekdikti 
added that SR (Sustainability Report) is a tool and impetus for firms to transparently disclose the implementation of social responsibility and its environment. Ruhana \& Hidayah (2020) stated that the SR disclosure aims to prepare information related to firm activities and to convey signals to stakeholders about firm's concerns for the social and surrounding environment. Dynamic firms that put concerns on the environment and society do not only prioritize finance because they are also concerned with the interests of shareholders or investors, and stakeholders. They will be sustainable and beneficial. In order to meet the demands of stakeholders they need to do it responsibly in carrying out activities that involve the environment (Ariyani \& Hartomo, 2018). However, the current condition is the emergence of the corona pandemic in Indonesia and it becomes an increasingly large challenge for sustainable development and economy because it has an impact on increasing poverty, inequality, and reducing the quality of education. The Vice President of the Republic of Indonesia, Amin (2020) also said that currently the government is striving to implement this sustainability concept in the economy in Indonesia.

Past research conducted by Fahad \& Nidheesh (2020) stated that there are various characteristics of a firm to conduct SR disclosure. One of them is that large companies are becoming the center of attention among the public and government and have more financial resources to implement SR (Bhatia \& Tuli, 2017). Research (Nguyen \& Nguyen, 2020) also stated that there are important factors driving SR, such as firm size and leverage. While other driving factors for SR are firm age (Fahad \& Nidheesh, 2020), profitability (Akbulut \& Kaya, 2019) and media visibility (Yu \& Liang, 2020). This study did not use control variables as has been done by most other studies. In this study, the control variables commonly used in research on disclosure of SR are used as independent variables which are hypothesized to have an effect on disclosure of SR. This is recommended by previous research conducted by Khan (2019) and Buallay et al. (2020).

The objective of this study is to obtain an overview of whether firm size, leverage, firm age, media visibility, and profitability can encourage firms to disclose SR or whether firms conduct SR voluntarily because they want to be transparent and accountable to stakeholders. The novelty in this study is to combine several independent variables from past research such as research by Abdulsalam\&Babangida (2020), Akbulut\& Kaya (2019), Ariyani \& Hartomo (2018), Fahad \& Nidheesh (2020), Gunarsih et al. (2020) and Ruhana \& Hidayah (2020) to test the relation with SR, also this study uses a robust test that is seen from the size of a firm.

Based on this explanation, this study formulates the following issues:

(1) What is the impact of the firm size on the disclosure on SR?,

(2) How is the impact of leverage on disclosure on SR?,

(3) How is the impact of firm age on disclosure on SR ?,

(4) How is the impact of profitability on disclosure on SR?, and

(5) What is the impact of the media on disclosure on SR?

\section{HYPOTHESES DEVELOPMENT}

Sustainability Reporting is a non-financial report consisting of three elements, which are economic performance, environmental performance, and social performance as well as sustainability reporting prepared based on GRI standards and GRI standards 
prepared as a set of interrelated standards (Gunarsih et al., 2020). SR disclosure has the objective of preparing a report related to the activities of a firm and being a factor for conveying messages to stakeholders regarding the firm's concern for social and environmental issues (Ruhana \& Hidayah, 2020).

The first determinant of SR is the firm size (Mashayekhi et al., 2019). firm size is a scale that is classified in different ways such as total assets, market value, number of employees, and others (Ruhana \& Hidayah, 2020). Larger firms have more stakeholders in their organization, therefore there is a tendency for these firms to seek legitimacy from more stakeholders who control the resources they need for firm operations (Abdulsalam \& Babangida, 2020). Research done by Abdulsalam \& Babangida (2020) and Akbulut \& Kaya (2019) stated that firm size and SR have a significant positive impact, which means that firms whose size are getting bigger will have more resources and information that must be passed to stakeholders. Meanwhile, Ariyani \& Hartomo (2018) stated that firm size does not have a significant impact on SR disclosure because of the larger the firm, the greater the political costs when compared to small firms.

\section{H1 : Firm size has a positive impact on SR disclosure}

Countries where their main source of corporate capital comes from third parties or creditors, thus firms with high financial leverage will tend to disclose more information to creditors, suppliers, and investors with the aim of creating greater confidence in creditors that the firm can meet its financial obligations and increase opportunities. Get a good investment from financial institutions (Nguyen \& Nguyen, 2020). Leverage is used by firms to fund their operations. Firms that have a high level of leverage are more likely to allow firms to violate credit agreements, so that firms could report sustainability reports to persuade and get credit loans from stakeholders. Because SR can fulfill shareholders or investors and stakeholders in running firm operations that are more concerned with the environment for the firm's sustainability goals (Ariyani \& Hartomo, 2018). In line with Ariyani \& Hartomo's research (2018), research conducted by Nguyen \& Nguyen (2020) also stated that leverage has a significant positive impact on SR, which means that SR can be used by a firm in obtaining debt from stakeholders.

Past research conducted by Ozcan (2019), stated that leverage has a positive and significant impact on SR disclosure, which means that firms have greater resource availability and lead to a higher number of activities to disclose. In line with this statement, Yu \& Liang's (2020) research also found that leverage has a significant positive impact on SR disclosure, while Fahad \& Nidheesh (2020) stated that leverage has a positive impact on environmental and social disclosure on SR and has a negative impact on SR disclosure. Disclosure of governance in SR. Another case with research done by Akbulut \& Kaya (2019) and Abdulsalam \& Babangida (2020) stated that leverage with SR disclosure has a significant negative impact because firms with a higher level of dependence on debt will prevent firms from investing in a sustainable manner.

\section{H2: Leverage has a positive impact on SR disclosure}

Companies that have been established or operated for a long time usually disclose information about the company's social and environmental activities (Fahad \& Nidheesh, 2020). This action is generally carried out with the aim of improving the company's image in society (Badulescu et al., 2018). This proves that the company has the experience to be sustainable in the business world. Research conducted by Fahad \& Nidheesh (2020) explains that firm age has a positive impact on environmental and social disclosures on 
SR, and has a negative impact on disclosure of governance on SR. It is different from Okoye \& Adeniyi's research (2018) which stated that firm age does not impact corporate social disclosure because both young and old firms report their corporate social responsibility.

\section{H3: Firm age has a positive impact on SR disclosure}

Media visibility is a medium for transparency of firm information with its aim of being recognized by the public (Humanitisri \& Ghozali, 2018) and communicating with investors (OuYang et al., 2017). When a firm has a great and big reputation, the firm experiences greater pressure in maintaining its strong reputation, like fulfilling the demands of stakeholders by expressing and engaging in their social responsibility activities (Yu \& Liang, 2020). One of the past studies stated that media visibility is an external determinant which is consistently found to have a significant positive impact on SR disclosure (Dienes et al., 2016). This is aligned with research by Gavana et al. (2017) which stated that media visibility increases corporate voluntary disclosure and shows that media visibility significantly impacts SR.

\section{H4: Media visibility has a positive impact on SR disclosure}

The main goal of a firm is to generate profitability (Ariyani \& Hartomo, 2018). Profitability is defined as the results obtained from management efforts on funds invested by firm owners (Anshori et al., 2020). The higher the profitability of the firm, the wider the firm will apply and disclose SR voluntarily. If the firm discloses the SR, investors will see the good side of the firm and the public's view will also be good for the firm so that the firm will get higher profitability (Ariyani \& Hartomo, 2018).

Research done by Gunarsih et al. (2020), stated that profitability has a negative impact on SR disclosure because the higher ROA, the lower the SR and ROA is detrimental to SR. On the other hand, research by Nguyen \& Nguyen (2020) and Ariyani \& Hartomo (2018) stated that profitability is one of the variables that have positive and significant influence on SR disclosure.

\section{H5: The firm's profitability has a positive impact on SR disclosure}

H6: Simultaneously firm size, leverage, firm age, media visibility and profitability have a positive effect on SR disclosure

\section{METHOD, DATA, AND ANALYSIS}

This research uses an explanatory research with a quantitative approach and aims to analyze and examine the relation between firm size, leverage, firm age, media visibility and profitability on SR disclosure. Explanatory research is a research that has the aim of obtaining explanations related to the cause and effect between each variables in the research (Solimun; et al., 2017). This research uses secondary data in the form of sustainability reporting and annual reports. This study uses a population of LQ 45 companies listed on the IDX and uses purposive sampling to determine the sample that will be used, with the criteria that the LQ 45 companies must issue a complete annual report and SR from 2014 - 2018, then obtained a sample of 18 companies LQ 45. This research uses multiple linear regression tests data analysis technique, with the help of EViews. 
To measure the firm size variable, the natural logarithm of total assets is used, leverage uses the debt to equity ratio with the following formula:

$$
\text { Debt to Equity Ratio }=\frac{\text { Total Debt }}{\text { Total Shareholders'Equity }}
$$

Firm age uses an indicator of the firm's own age, media visibility uses an indicator of advertising intensity with the following formula:

$$
\text { Advertising Intensity }=\frac{\text { Advertising fee }}{\text { Total of sales }}
$$

Then, profitability is measured by the Return on Assets Ratio (ROA) with the following formula:

$$
R O A=\frac{\text { Net Income }}{\text { Total Assets }}
$$

While the measurement for the SR variable uses the indicators on the environmental, economic, and social dimensions. The indicator items used are guided by the assessment according to the Sustainability Report Disclosure Index (SRDI) G4 Global Reporting Initiatives (2013) with a total of 77 indicators. The scoring mechanism is conducted by using scoring, and by giving a value of 1 if an item is disclosed or giving a value of 0 if it is not disclosed. After the scoring is completed and being totaled from each samples according to each indicators.

\section{RESULTS}

\section{Multiple Linear Regression}

Multiple linear regression is used to analyze the impact of firm size, leverage, firm age, media visibility, and profitability on SR disclosure with the following equation: $Y=a+\beta X 1+\beta X 2+\beta X 3+\beta X 4+\beta X 5+e$

Notes:

$\mathrm{Y}=$ disclosure sustainability report, $\mathrm{a}=$ Constanta, $B=$ Regression Coeficcient, $\mathrm{X} 1=$ firm size, $\mathrm{X} 2=$ leverage, $\mathrm{X} 3=$ firm age, $\mathrm{X} 4=$ media visibility, $\mathrm{X} 5=$ profitability, $\mathrm{e}=$ error. 
Table 1. Multiple Linear Regression Test Result

\begin{tabular}{|c|c|c|c|}
\hline \multicolumn{2}{|c|}{ "Variable } & "Coefficient & Prob. \\
\hline \multicolumn{2}{|c|}{ C } & 4.809943 & 0.0000 \\
\hline \multicolumn{2}{|c|}{ Firm Size } & 0.082189 & 0.0949 \\
\hline \multicolumn{2}{|c|}{ Leverage } & -0.057505 & 0.0000 \\
\hline \multicolumn{2}{|c|}{ Firm Age } & -1.615948 & 0.0002 \\
\hline \multicolumn{2}{|c|}{ Media Visibility } & 0.376218 & 0.4786 \\
\hline \multicolumn{2}{|c|}{ Profitability } & 0.816277 & 0.0253 \\
\hline R-squared & 0.622007 & & \\
\hline F-statistic & 5.011463 & & \\
\hline Prob (F-statistic) & 0.000000 & & \\
\hline
\end{tabular}

Source: Output Result Panel, Eviews 9

Based on the results of the calculations in table 1, the multiple linear regression equation is obtained as follows:

$\mathrm{Y}=4.809943+0.082189 \mathrm{X} 1-0.057505 \mathrm{X} 2-1.615948 \mathrm{X} 3+0.376218 \mathrm{X} 4+0.816277 \mathrm{X} 5+\mathrm{e}$

Where:

* The regression coefficient X1 is 0.082189 , which states that every increment of 1 unit in firm size will increase the SR disclosure by 0.082189 .

* The regression coefficient X2 is -0.057505 , which states that every increment of 1 unit in leverage will reduce the SR of disclosure by 0.057505 .

* The regression coefficient of X3 is -1.615948 , which states that every increment of 1 unit in firm age will decrease the SR disclosure by 1.615948.

* The X4 regression coefficient of 0.376218 , which states that every increment of 1 unit in media visibility will increase disclosure SR by 0.376218 .

* The regression coefficient X5 is 0.816277 , which states that every increment of 1 unit in profitability will increase the SR disclosure by 0.816277 .

\section{Simultaneous Testing (F Testing)}

The $\mathrm{F}$ test is used in testing the regression coefficient as a whole to determine the impact of variable $X$ simultaneously on variable $Y$, and the following results are obtained:

Based on the results of the test on Table 1, the probability value of $\mathrm{F}$ statistic is 0.000000 and the $F$ value is calculated as 5.011463 . With a significance value less than 0.05 , it can be concluded that the Ho hypothesis is rejected, which means that at the $5 \%$ significance level, there is a simultaneous significant impact of firm size, leverage, firm age, media visibility and profitability on SR disclosure.

\section{Partial Test (T Testing)}

Partial testing is conducted to determine the impact of one independent variable on the dependent variable assuming the other variables are constant, and the following results are obtained: 
Table 2. Summary of t Test Results for Multiple Linear Regression

\begin{tabular}{ccc}
\hline \hline Variable & Coefficient & Prob. \\
\hline \hline C & 4.809943 & 0.0000 \\
Firm Size & 0.082189 & 0.0949 \\
Leverage & -0.057505 & 0.0000 \\
Firm Age & -1.615948 & 0.0002 \\
Media Visibility & 0.376218 & 0.4786 \\
Profitability & 0.816277 & 0.0253 \\
\hline \hline
\end{tabular}

Source: data panel output result, Eviews 9

Based on the results of the tests, the p-value of the firm size is 0.0949>0.05, which means that $\mathrm{H} 01$ is accepted and shows that partially, firm size does not have a significant impact on SR disclosure or that the measurements of the firm size will not affect SR disclosure.

Leverage is known to have a p-value of $0.0000<0.05$, which means that $\mathrm{H} 02$ is rejected and it indicates that partially, leverage has a significant negative impact on SR disclosure or the higher the leverage level of a firm, the smaller the SR disclosure level will be.

Firm age is known to have a p-value of $0.0002<0.05$, which means that $\mathrm{H} 03$ is rejected and it indicates that partially, firm age has a significant negative impact on SR disclosure or the older the firm is, the smaller the SR disclosure level will be.

Media visibility is known to have a p-value of $0.4786>0.05$, which means that $\mathrm{H} 04$ is accepted and it indicates that partially, media visibility does not have a significant impact on SR disclosure or the measurement of media visibility will not affect SR disclosure.

Profitability is known to have a p-value of $0.0253<0.05$, which means that H05 is rejected and it indicates that financial performance has a significant impact on SR disclosure or the increase in profitability will also increase the level of SR disclosure.

\section{Robustness Check}

To ensure that the results of the regression are valid, an inspection is conducted using the Robust Least Square with the M-estimation method by dividing large and small firms, the following results are obtained:

Table 3. Robustness Check Result

Dependent Variable: $Y$

Method: Robust Least Squares

Date: 09/17/20 Time: 12:20

Sample: 20142018

Included observations: 90

Method: M-estimation

M settings: weight $=$ Bisquare, tuning $=4.685$, scale $=$ MAD (median centered)

Huber Type I Standard Errors \& Covariance 


\begin{tabular}{|c|c|c|c|c|}
\hline Variable & Coefficient & Std. Error & z-Statistic & Prob. \\
\hline $\mathrm{C}$ & 0.551898 & 0.171664 & 3.214997 & 0.0013 \\
\hline $\mathrm{X} 1$ & 0.019962 & 0.036718 & 0.543645 & 0.5867 \\
\hline $\mathrm{X} 2$ & $-8.83 \mathrm{E}-05$ & 0.006420 & -0.013761 & 0.9890 \\
\hline $\mathrm{X} 3$ & -0.071839 & 0.048226 & -1.489638 & 0.1363 \\
\hline $\mathrm{X} 4$ & -0.131927 & 0.151378 & -0.871505 & 0.3835 \\
\hline X5 & 0.138863 & 0.207666 & 0.668685 & 0.5037 \\
\hline \multicolumn{5}{|c|}{ Robust Statistics } \\
\hline R-squared & 0.033074 & \multicolumn{2}{|l|}{ Adjusted R-squared } & -0.024481 \\
\hline Rw-squared & 0.060860 & \multicolumn{2}{|l|}{ Adjust Rw-squared } & 0.060860 \\
\hline Akaike info criterion & 114.1895 & \multicolumn{2}{|l|}{ Schwarz criterion } & 130.8893 \\
\hline Deviance & 1.800614 & \multicolumn{2}{|l|}{ Scale } & 0.131650 \\
\hline Rn-squared statistic & 3.854232 & \multicolumn{2}{|l|}{ Prob(Rn-squared stat.) } & 0.570588 \\
\hline \multicolumn{5}{|c|}{ Non-robust Statistics } \\
\hline Mean dependent var & 0.324386 & \multicolumn{2}{|c|}{ S.D. dependent var } & 0.176172 \\
\hline S.E. of regression & 0.181320 & \multicolumn{2}{|c|}{ Sum squared resid } & 2.761657 \\
\hline
\end{tabular}

Source: data panel output result, Eviews 9

Based on the results of the tests conducted, it indicates that the coefficient value obtained is different from the EGLS (fixed model), as well as the conclusion obtained.

\section{DISCUSSION}

The results of the tests which were conducted show that there is no impact of firm size on SR disclosure, the results are align with research conducted by Ariyani \& Hartomo (2018) who stated that firm size does not have an impact on SR disclosure. The results of tests for leverage indicates that leverage has a significant and negative impact on SR disclosure and is aligned with the research of Akbulut \& Kaya (2019) and Abdulsalam \& Babangida (2020). Firm age indicates that firm age has a negative and significant impact on SR disclosure and these results are contrary to what Fahad \& Nidheesh (2020) stated, that firm age has a psotive impact on SR. Media visibility indicates that media visibility has no impact on SR disclosure and this is contrary to what Gavana et al. (2017) stated, that media visibility has an impact on SR disclosure. The last is the profitability variable indicates that firm's profitability has a significant impact on SR disclosure and is aligned with the research conducted by Ariyani \& Hartomo (2018) and 
Nguyen \& Nguyen (2020), who stated that profitability has a significant impact on SR disclosure.

Firm size in Nigeria is one of the factors affecting the SR because the bigger the firm is, the more stakeholders it has (Abdulsalam \& Babangida, 2020), but in Indonesia, firm size is not an important factor which affects SR, apart from firm size, media visibility is not one of the factors affecting SR because companies that already have a good reputation do not report and disclose SR to increase public trust. In Indonesia, profitability has become the major factor and has a positive impact on SR, which reflects that firms which have higher profits will have a high level of SR disclosure as well. In addition, firm age and leverage have a significant negative impact on SR disclosure because old firms have a lot of experience and have a good reputation on community and they built trust on the people and stakeholders, regardless of how the firm concerns for the economy, environment and social society.

\section{CONCLUSION, LIMITATIONS, AND SUGGESTIONS}

\section{Conclusion}

The result of simultaneous testing indicates that there is a significant impact of firm size, firm age, media visibility and profitability on SR disclosure. Meanwhile, the result of research with partial testing indicates that firm size and media visibility have no impact on SR disclosure or in other words, the greater the firm size and the higher the level of media visibility of the firm, they will not affect the SR disclosure level. Leverage and firm age have a negative and significant impact on SR disclosure, which means that the older a firm is and the higher the level of leverage, the smaller the SR disclosure level will be. Another case of profitability which was found to have a positive and significant impact on SR disclosure, which means that the increment in firm's profitability will also increase the level of SR disclosure. The test results reflect that firms will increase and implement SR if their profitability increases, but firms which are implementing SR do not use funds originating from loans or debt, because funds which are sourced from the third parties or creditors are used to invest which will increase the companies' profitability, whereas older firms have more experience and customers have more trust in their products so that the older a firm is, the smaller the SR disclosure level will be. Firm size and the measurement of media visibility of a firm will not affect a firm to implement SR. The suggestion is that a firm should implement and disclose SR, not based on the profitability of the firm, because SR is a form of a concern for the environment and society, especially the community around the firm, and shareholders and even customers, they prefer firms that put concerns on the environment and social, and also to build stakeholders trust on the firms which have conducted and disclosed SR compared to the firms that do not conduct and disclose their SR.

\section{Limitation and suggestions}

The limitation in this study is that it does not use control variables in this research model and does not test many other factors that can affect SR disclosure. The suggestion for further research is to add control variables in research such as industry affiliation, corporate governance and ownership. 


\section{ACKNOWLEDGEMENT}

This research could not have proceeded without the funding from The Ministry of Research, Technology and Higher Education Republic of Indonesia.

\section{REFERENCES}

Abdulsalam, N., \& Babangida, M. A. (2020). Effect of Sales and Firm Size on Sustainability Reporting Practice of Oil and Gas Companies in Nigeria. Quest Journals Journal of Research in Business and Management, 8(1), 2347-3002. www.questjournals.org

Akbulut, D. H., \& Kaya, I. (2019). Sustainability reporting and firm performance. Pressacademia, 9(9), 81-84. https://doi.org/10.17261/pressacademia.2019.1071

Amin, M. (2020, August 27). Wapres: Akibat Pandemi Covid-19, Tantangan Pembangunan Ekonomi Berkelanjutan Semakin Besar. Kompas.Com. https://nasional.kompas.com/read/2020/08/27/13054261/wapres-akibatpandemi-covid-19-tantangan-pembangunan-ekonomi-berkelanjutan

Anshori, M. Y., Herlambang, T., Karya, D. F., Muhith, A., \& Rasyid, R. A. (2020). Profitability estimation of a Company in PT.ABCD using extended kalman filter. Journal of Physics: Conference Series, 1538(1). https://doi.org/10.1088/17426596/1538/1/012036

Ariyani, A. P., \& Hartomo, O. D. (2018). Analysis Of Key Factors Affecting The Reporting Disclosure Indexes Of Sustainability Reporting In Indonesia. International Journal of Business, Economic and Law, 16(1), 15-25.

Badulescu, A., Badulescu, D., Saveanu, T., \& Hatos, R. (2018). The relationship between firm size and age, and its social responsibility actions-Focus on a developing $\begin{array}{llll}\text { country (Romania). } & \text { Sustainability } & \text { (Switzerland), }\end{array}$ https://doi.org/10.3390/su10030805

Bhatia, A., \& Tuli, S. (2017). Corporate attributes affecting sustainability reporting: an Indian perspective. International Journal of Law and Management, 59(3), 322-340. https://doi.org/10.1108/IJLMA-11-2015-0057

Buallay, A., Fadel, S. M., Al-Ajmi, J. Y., \& Saudagaran, S. (2020). Sustainability reporting and performance of MENA banks: is there a trade-off? Measuring Business Excellence, 24(2), 197-221. https:// doi.org/10.1108/MBE-09-2018-0078

Dienes, D., Sassen, R., \& Fischer, J. (2016). What are the drivers of sustainability reporting? A systematic review. Sustainability Accounting, Management and Policy Journal, 7(2), 154-189. https://doi.org/10.1108/SAMPJ-08-2014-0050

Fahad, P., \& Nidheesh, K. B. (2020). Determinants of CSR disclosure: an evidence from India. Journal of Indian Business Research. https://doi.org/10.1108/JIBR-06-2018-0171

Gavana, G., Gottardo, P., \& Moisello, A. M. (2017). Sustainability reporting in family firms: A panel data analysis. Sustainability (Switzerland), 9(1), 1-18. 
https://doi.org/10.3390/su9010038

Gunarsih, T., Setiyono, S., Sayekti, F., \& Novak, T. (2020). Bi-directional in sustainability reporting and profitability: A study in Indonesian banks and non-banks. Jurnal Keuangan Dan Perbankan, 24(1), 20-29. https://doi.org/10.26905/jkdp.v24i1.3588

Hahn, R., \& Kühnen, M. (2013). Determinants of sustainability reporting: A review of results, trends, theory, and opportunities in an expanding field of research. Journal of Cleaner Production, 59, 5-21. https://doi.org/10.1016/j.jclepro.2013.07.005

Humanitisri, N., \& Ghozali, I. (2018). Perusahaan Sebagai Variabel Mediasi, Dan Visibilitas Sebagai Variabel Moderasi Dalam Hubungan Antara Csr Dengan Reputasi (Studi Empiris Pada Perusahaan Manufaktur Yang Terdaftar Di Bursa Efek Indonesia Periode 2015-2016). Diponegoro Journal of Accounting, 7(4), 1-13.

Khan, M. (2019). Corporate Sustainability Practices Impact on Firm Financial Performance: Evidence from the Banking Sector of Pakistan. City University Research Journal, 9(2), 427-438.

Mashayekhi, B., Taheri, H. S., \& Taheri, M. M. (2019). A Survey on Corporate Sustainability Reporting: The Case of Iran. Journal of Finance and Accounting, 7(3), 76. https://doi.org/10.11648/j.jfa.20190703.12

Nasir, M. (2018, February 24). No Title. Detik.Com. https://news.detik.com/berita-jawatengah/d-3883988/menristekdikti-dorong-perusahaan-aktif-kelola-lingkungan

Nguyen, A. H., \& Nguyen, L. H. (2020). Determinants of sustainability disclosure: Empirical evidence from vietnam. Journal of Asian Finance, Economics and Business, 7(6), 73-84. https:// doi.org/10.13106/JAFEB.2020.VOL7.NO6.073

Okoye, E. I., \& Adeniyi, S. I. (2018). Effect of Financial Leverage on Voluntary Corporate Social Disclosure among Listed Firms on Nigerian Stock Exchange: A Study of Selected Manufacturing Firms. Academic Journal of Economic Studies, 4(3), 18-24.

OuYang, Z., Xu, J., Wei, J., \& Liu, Y. (2017). Information Asymmetry and Investor Reaction to Corporate Crisis: Media Reputation as a Stock Market Signal. Journal of Media Economics, 30(2), 82-95. https://doi.org/10.1080/08997764.2017.1364256

Ozcan, I. C. (2019). Determinants of Environmental, Social, and Governance Disclosure Performance of Publicly Traded Airports Determinants of Environmental, Social, and Governance Disclosure Performance of Publicly Dr. İsmail Çağrn Özcan Ankara Yıldırım Beyazıt Universit. December.

Ruhana, A., \& Hidayah, N. (2020). The Effect of Liquidity, Firm Size, and Corporate Governance Toward Sustainability Report Disclosures (Survey on: Indonesia Sustainability Report Award Participant). 120(Icmeb 2019), 279-284. https://doi.org/10.2991/aebmr.k.200205.048

Solimun;, Fernandes, adji A. rinaldo;, \& Nurjannah; (2017). Metode Statistika Multivariat Pemodelan Persamaan Struktural (SEM) Pendekatan WarpPLS. UB Press. 
Yu, S. H., \& Liang, W. C. (2020). Exploring the determinants of strategic corporate social responsibility: An empirical examination. Sustainability (Switzerland), 12(6), 1-16. https://doi.org/10.3390/su12062368 